\title{
Disulfide formation in bovine zona pellucida glycoproteins during fertilization: evidence for the involvement of cystine cross-linkages in hardening of the zona pellucida
}

\author{
K. Iwamoto ${ }^{1}$, K. Ikeda ${ }^{2}$, N. Yonezawa ${ }^{1,2}$, S. Noguchi ${ }^{2}$, K. Kudo $^{2}$, S. Hamano ${ }^{3}$, \\ M. Kuwayama ${ }^{3}$ and M. Nakano ${ }^{1,2 *}$ \\ ${ }^{1}$ Department of Chemistry, Faculty of Science and ${ }^{2}$ Graduate School of Science and Technology, Chiba University, 1-33 Yayoi-cho, \\ Inage-ku, Chiba 263-8522, Japan; and ${ }^{3}$ Animal Bio-Technology Center, Livestock Improvement Association, Tokyo, Japan
}

\begin{abstract}
The time for solubilization of the bovine zona pellucida in a hypotonic buffer containing $5 \%(\mathrm{v} / \mathrm{v}) \beta$-mercaptoethanol and $7 \mathrm{~mol}$ urea $\mathrm{l}^{-1}$ increased by $10 \%$ after fertilization. Coupling with a specific fluorescent thiol probe, monobromobimane $(\mathrm{mBBr})$, was markedly greater in the zona pellucida of ovarian eggs compared with fertilized eggs, indicating that the cysteine residues in the zona pellucida of unfertilized eggs are oxidized to cystines during fertilization. After endo- $\beta$-galactosidase digestion to remove $N$-acetyllactosamine repeats of the carbohydrate chains, three zona pellucida glycoproteins (ZPA, ZPB and ZPC) coupled with the fluorescent bimane groups were fractionated efficiently by reverse-phase HPLC. Estimation of bimane groups in the three components and SDS-PAGE revealed that intramolecular disulfide bonds in ZPA and intra- and intermolecular disulfide bonds in $\mathrm{ZPB}$ were formed during fertilization, but oxidation of cysteine residues in ZPC was low. Specific proteolysis of ZPA during fertilization was also observed. These results indicate that the formation of disulfide linkages together with specific proteolysis result in the construction of a rigid zona pellucida structure, which is responsible for hardening of the zona pellucida.
\end{abstract}

\section{Introduction}

The zona pellucida is one of the two sites at which polyspermy is blocked (Wolf, 1981; Stewart-Savage and Bavister, 1988; Yanagimachi, 1994). After fertilization in most mammals, cortical granules in the oocyte are broken and the materials released into the perivitelline space act on the zona pellucida, resulting in hardening (Braden et al., 1954; Austin and Braden, 1956; Barros and Yanagimachi, 1971; Drobnis et al., 1988). The hardening of the zona pellucida together with cortical granule-independent changes in the plasma membrane are generally accepted to be responsible for blocking polyspermy. After fertilization in mice, a protein component of the zona pellucida, ZP2, is cleaved specifically by a protease released from the cortical granules (Bleil et al., 1981; Moller and Wassarman, 1989). The specific cleavage of a component during fertilization is also observed in the pig and bovine zona pellucida (Hedrick et al., 1987; Hatanaka et al., 1992; Noguchi et al., 1994). However, correlation of the specific cleavage with hardening of the zona pellucida remains to be determined. Schmell and Gulyas (1980), using an indirect method in a study of mice, proposed that the

* Correspondence.

Received 28 October 1998. cross-linkages between tyrosine residues of the zona pellucida proteins formed by ovoperoxidase caused the hardening. In contrast to sea urchins (Foerder and Shapiro, 1977), dityrosyl residues have not been found in the zonae pellucidae of fertilized eggs in mice. However, cross-linkages of disulfide bonds in zona pellucida proteins in rats are thought to be involved in hardening of the zona pellucida (Zhang et al., 1991).

It is necessary to compare the properties and structure of the zona pellucida of a fertilized egg with that of an unfertilized egg to understand the function of the zona pellucida. However, the limited availability of fertilized mammalian eggs has prevented molecular analysis. In the present study, a large number of fertilized bovine eggs were produced by in vitro fertilization (IVF) and the properties of the zona pellucida were compared with those of ovarian eggs.

The nomenclature for zona pellucida proteins from different species is confusing (Hedrick, 1996). Bleil and Wassarman (1980) designated three glycoproteins from the mouse zona pellucida as ZP1, ZP2 and ZP3 from the highest molecular mass to the lowest, respectively. However, the size of the ZP1 gene, which forms a dimeric structure after biosynthesis, is smaller than that of ZP2. Harris et al. (1994) proposed that the protein genes should be termed $Z P A, Z P B$ 
and $Z P C$ according to the size of the cDNA: ZPA for the largest and ZPC for the smallest. Three native glycoproteins of the bovine zona pellucida have similar molecular masses due to heterogeneous carbohydrate chains, although the sizes of their protein skeletons are different (Noguchi et al., 1994). The terminology used in the present study is as follows: $\mathrm{ZPA}, \mathrm{ZPB}$ and $\mathrm{ZPC}$ proteins that are gene products of $Z P A, Z P B$ and $Z P C$ genes, respectively. Incorporation of the bimane group into these three zona pellucida proteins was also investigated in this study.

\section{Materials and Methods}

\section{Preparation of ovarian, matured and fertilized bovine eggs}

Ovarian, matured and fertilized bovine eggs and their zonae pellucidae were prepared as described by Hamano and Kuwayama (1993) and Noguchi et al. (1994). Ovaries were obtained from an abattoir. Within $1 \mathrm{~h}$ after animals were killed, cumulus-egg complexes were isolated from the ovaries and were matured to metaphase II in TCM 199 containing $5 \%(\mathrm{w} / \mathrm{v})$ fetal bovine serum at $38.5^{\circ} \mathrm{C}$ for $21 \mathrm{~h}$ under $2 \% \mathrm{CO}_{2}$ in air. Matured eggs in $\mathrm{BO}$ medium (Brackett and Oliphant, 1975) containing $1 \%(\mathrm{w} / \mathrm{v})$ BSA were fertilized with spermatozoa capacitated in $\mathrm{BO}$ medium, and were incubated at $37^{\circ} \mathrm{C}$. Differentiation of the embryos was terminated by freezing at the two-cell, four-cell, eightcell, 16-cell and morula stages. The embryos were stored at $-80^{\circ} \mathrm{C}$ until use. In the chromatographic and electrophoretic analyses, a mixture of embryos from the two- to the 16-cell stages was used as the fertilized eggs, whereas ovarian eggs before fertilization were used as the unfertilized group.

\section{Zona pellucida solubilization assay}

Ten ovarian eggs and ten fertilized eggs at each stage were placed separately in various media (Table 1 ) at $25^{\circ} \mathrm{C}$ and the time required for complete lysis of the zona pellucida was recorded.

\section{Modification of isolated zonae pellucidae with $\mathrm{mBBr}$}

Zonae pellucidae were isolated by removing the ooplasm from the eggs by pipetting with a narrow bore pipette. The isolated zonae pellucidae were modified with monobromobimane $(\mathrm{mBBr})$ (Calbiochem, La Jolla, CA) using a stock solution of $50 \mathrm{mmol} \mathrm{l}^{-1} \mathrm{mBBr}$ in acetonitrile. $\mathrm{mBBr}$ was added to the isolated zonae pellucidae in $50 \mathrm{ml}$ PBS containing $0.3 \%$ $(\mathrm{w} / \mathrm{v})$ EDTA to a final concentration of $0.5 \mathrm{mmol} \mathrm{mBBr}^{-1}$ and the suspension was incubated at $25^{\circ} \mathrm{C}$ for $1 \mathrm{~h}$ in the dark. The modified zonae pellucidae were washed three times with fresh PBS by centrifugation at $1000 \mathrm{~g}$ for $5 \mathrm{~min}$.

\section{Examination by fluorescence microscopy of the isolated zonae pellucidae modified with $\mathrm{mBBr}$}

The features of the modified zonae pellucidae were observed and photographed with an Olympus BH2-QRFL fluorescence microscope using Kodak Tri-X film.

\section{Incorporation of bimane group into the zona pellucida glycoproteins of ovarian and fertilized eggs}

The zonae pellucidae isolated from approximately 3000 ovarian and fertilized eggs were modified with $0.5 \mathrm{mmol}$ $\mathrm{mBBr} \mathbf{l}^{-1}$ in PBS containing $0.3 \%(\mathrm{w} / \mathrm{v})$ EDTA for $1 \mathrm{~h}$. After removal of the excess reagents by several transfers to fresh PBS, the zonae pellucidae were solubilized by heating at $70^{\circ} \mathrm{C}$ in $\mathrm{H}_{2} \mathrm{O}$. The heat-solubilized zonae pellucidae were digested with endo- $\beta$-galactosidase $(1 \mathrm{mU})$ at $37^{\circ} \mathrm{C}$ for $48 \mathrm{~h}$ to remove $\mathrm{N}$-acetyllactosamine regions in the carbohydrate chains (Noguchi et al., 1994). Desalting was performed by Nucleosil $300-7$ C18 HPLC using $0.1 \%(\mathrm{w} / \mathrm{v})$ trifluoroacetic acid in $90 \%$ $(\mathrm{w} / \mathrm{v})$ acetonitrile as an eluent. Glutathione (reduced form) modified with $\mathrm{mBBr}$ was used as a control and the excess reagents were removed by elution with $20 \mathrm{mmol}$ ammonium acetate $\mathrm{l}^{-1}$ on a Bio-Gel P2 column. The amount of bimane group incorporated into the zona pellucida proteins was estimated by measuring the fluorescence intensity at $483 \mathrm{~nm}$ with excitation at $405 \mathrm{~nm}$ of the $\mathrm{mBBr}$-modified (mB-) proteins against the modified glutathione (mB-glutathione).

Table 1. Solubilization time of bovine zonae pellucidae of ovarian and fertilized eggs

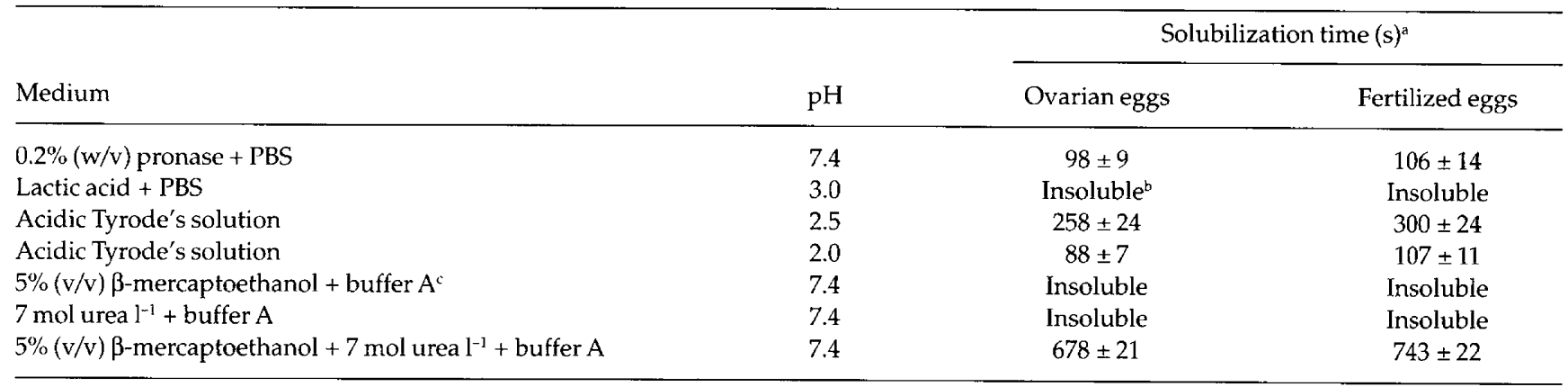

"Twenty eggs were placed in the medium at $25^{\circ} \mathrm{C}$ and the time (mean $\pm \mathrm{SD}$ ) required for complete lysis of the zonae pellucidae was recorded. 'Insoluble: no change in the zonae pellucidae was observed after $24 \mathrm{~h}$.

Buffer A: $10 \mathrm{mmol}$ Tris-HCl $1+0.4 \%(\mathrm{w} / \mathrm{v})$ polyvinylpyrrolidone. 
Fractionation of endo- $\beta$-galactosidase digests of $m B r$-zona pellucida proteins into three components

After mBr-zona pellucida proteins from approximately 3000 ovarian and fertilized eggs were digested with endo- $\beta$ galactosidase as described above, the digests were subjected to chromatography on a reverse-phase HPLC column (Nucleosil $300-7 \mathrm{C} 18$ column, $4 \mathrm{~mm} \times 150 \mathrm{~mm}$ ) by an increasing concentration of acetonitrile in $0.1 \%(\mathrm{w} / \mathrm{v})$ trifluoroacetic acid at a flow rate of $1.0 \mathrm{ml} \mathrm{min}^{-1}$. An identical amount of protein estimated by amino acid analysis was applied in each chromatography. Absorbance at $210 \mathrm{~nm}$ and fluorescence intensity at $483 \mathrm{~nm}$ with excitation at $405 \mathrm{~nm}$ were monitored. The fractions including the zona pellucida proteins were subjected to SDS-PAGE under non-reducing and reducing conditions, and three zona pellucida glycoproteins (ZPA, ZPB and ZPC) were identified by the molecular masses of the bands.

\section{Gel filtration HPLC of the last peak on the reverse-phase HPLC}

The last peak on reverse-phase HPLC (fraction 5) was lyophilized and applied to a TSK-gel G3000SW column equilibrated with $3.5 \mathrm{mmol} \mathrm{SDS} \mathrm{l}^{-1}, 100 \mathrm{mmol}$ sodium sulfate $\mathrm{l}^{-1}$ and $50 \mathrm{mmol}$ sodium phosphate $\mathrm{l}^{-1}(\mathrm{pH}$ 7.0). The elution was performed with the equilibration buffer at a flow rate of $0.4 \mathrm{ml} \mathrm{min}^{-1}$.

\section{Estimation of incorporation of the bimane group into the three components}

The amount of bimane group incorporated into the three components was estimated using mB-glutathione as the standard as described above.

\section{Amino acid and $N$-terminal sequence analyses}

The amounts of proteins and glutathione were determined by amino acid analysis (Nakano et al., 1987). N-terminal amino acid sequences were determined by automated Edman degradation using an on-line model 120A phenylthiohydantoin amino acid analyser.

\section{Results}

\section{Changes in solubility of the zona pellucida during fertilization}

The time for lysis of the zona pellucida of fertilized eggs in $0.2 \%(\mathrm{w} / \mathrm{v})$ pronase-PBS was slightly greater than that for ovarian eggs (Table 1). Without pronase, the zonae pellucidae were not solubilized at $\mathrm{pH}>3.0$. At $\mathrm{pH} 2.5$ and 2.0 , the duration of lysis of the zona pellucida of fertilized eggs was slightly greater than that of ovarian eggs. Thus, in PBS containing pronase and acidic solutions, the increase in the

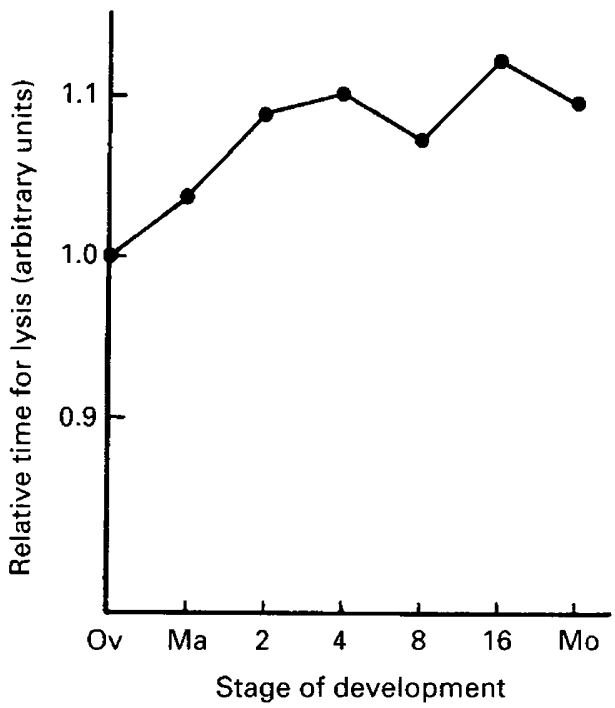

Fig. 1. Relative times required for complete lysis of the bovine zona pellucida at various stages of development. Ovarian eggs (Ov), matured eggs (Ma), and embryos at the two-cell (2), four-cell (4), eight-cell (8), 16-cell (16) and morula (Mo) stages were suspended separately in medium containing $5 \%(\mathrm{v} / \mathrm{v}) \beta$-mercaptoethanol, $7 \mathrm{~mol}$ urea $\mathrm{l}^{-1}, 0.4 \%(\mathrm{w} / \mathrm{v})$ polyvinylpyrrolidone and $10 \mathrm{mmol}$ Tris- $\mathrm{HCl} \mathrm{l} \mathrm{l}^{-1}$ ( $\mathrm{pH} 7.4$ ), and the times required for lysis relative to lysis of the zonae pellucidae of ovarian eggs were calculated. Duplicate experiments using a total of 20 eggs for each stage were performed. Standard deviations of the solubilization time were within $3 \%$.

time of solubilization of the zona pellucida after fertilization was small. The zonae pellucidae were not solubilized in 5\% (v/v) $\beta$-mercaptoethanol or $7 \mathrm{~mol}$ urea $\mathrm{l}^{-1}$, but were solubilized in a mixture of both reagents, in which the time of solubilization of zonae pellucidae from fertilized eggs was greater than those from ovarian eggs ( 743 versus $678 \mathrm{~s}$ ). The times for lysis of the zonae pellucidae of matured eggs and embryos at various stages of development in the $\beta$ mercaptoethanol-urea solution relative to that of ovarian eggs are shown (Fig. 1). From the two-cell to the morula stage, about a $10 \%$ increase in the time for lysis was observed. The standard deviation of the solubilization time of the zonae pellucidae at each stage was within $3 \%$. It is unclear why there was a small increase in solubilization time for zonae pellucidae from matured eggs compared with ovarian eggs.

\section{Modification of the isolated zonae pellucidae of unfertilized and fertilized eggs with $\mathrm{mBBr}$}

The zonae pellucidae isolated from ovarian eggs were strongly coupled with $\mathrm{mBBr}$, while those from the fertilized eggs at the two-cell stage were very weakly coupled (Fig. 2).

\section{Incorporation of bimane group into the zona pellucida protein mixture from ovarian and fertilized eggs}

The bovine zona pellucida is composed of three glycoproteins termed ZPA, ZPB and ZPC from the highest 


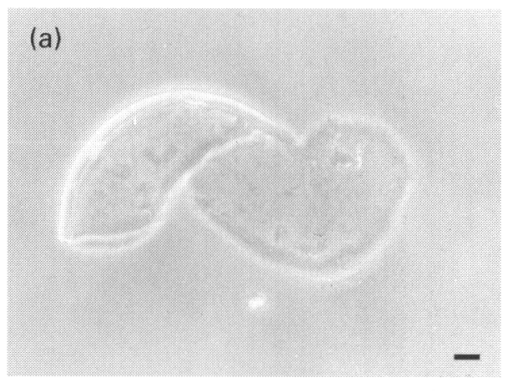

(c)
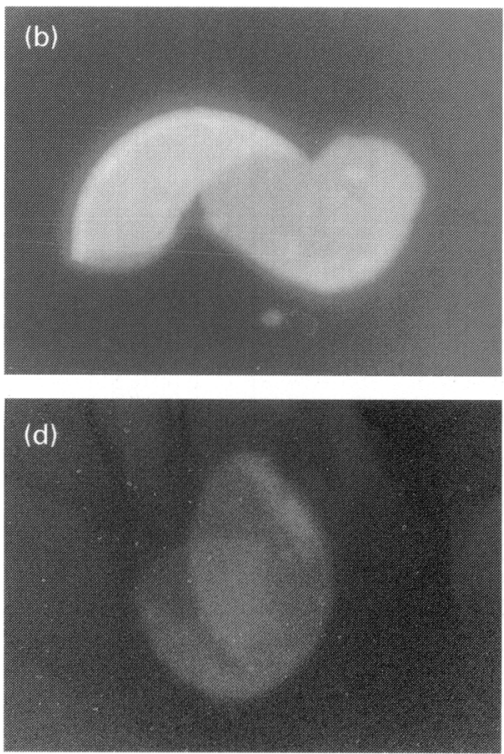

Fig. 2. Paired phase-contrast $(a, c)$ and fluorescence $(b, d)$ photomicrographs of representative bovine zonae pellucidae of a total of 30 zonae pellucidae modified with monobromobimane $(\mathrm{mBBr})$ after isolation. The isolated zonae pellucidae from ovarian eggs $(\mathrm{a}, \mathrm{b})$ and embryos at the two-cell stage $(\mathrm{c}, \mathrm{d})$ were fixed with $3 \%(\mathrm{v} / \mathrm{v})$ glutaraldehyde. Duplicate experiments were performed at each stage. Scale bars represent $15 \mu \mathrm{m}$.

molecular mass of protein skeleton to the lowest, respectively (Harris et al., 1994). The molecular masses of these protein skeletons are 63,41 and $34 \mathrm{kDa}$, respectively (Noguchi et al., 1994). The molar ratio of the protein moiety of three bovine zona components (ZPA:ZPB:ZPC) calculated from their molecular masses and amino acid composition was about 1:1:2. The amount of the bimane group incorporated into the protein mixture was estimated on the basis of the fluorescence intensities of bimane groups coupling to the protein mixture relative to that of $\mathrm{mB}$ glutathione (Table 2). The incorporation into the zonae pellucidae of fertilized eggs was low.

Fractionation of the zona pellucida proteins coupled with the bimane group

Separation of the three components of native bovine zona pellucida protein is difficult due to a prominent heterogeneity of carbohydrate chains (Noguchi et al., 1994). When the digests of the heat-solubilized zonae pellucidae with endo- $\beta$-galactosidase were applied to a reverse-phase HPLC column, a good and reproducible separation of the $\mathrm{mBr}$-zona pellucida protein mixture into three components was achieved (Fig. 3). SDS-PAGE of every peak (Fig. 4) revealed that the three components coupled with the bimane group were eluted in the following order: endo- $\beta$ galactosidase digested-ZPC, -ZPB and -ZPA and the last peak (fraction 5) which contained ZPA and high molecular mass multimers (HMM) of the zona pellucida protein. Fluorescence of ZPA and ZPB was almost undetectable after fertilization, although there was not a marked change in the amount of protein, indicating that intramolecular disulfide
Table 2. Number of bimane groups incorporated into the zona pellucida proteins of ovarian and fertilized bovine eggs

Bimane groups introduced $\left(\mathrm{mol} \mathrm{mol}^{-1}\right)$

\begin{tabular}{ll}
\hline Zona pellucida protein mixture of & \\
ovarian egg & 0.37 \\
ZPA & 0.25 \\
ZPB & 0.09 \\
ZPC & 0.07 \\
Zona pellucida protein mixture of & \\
fertilized egg & 0.05 \\
ZPA & 0.01 \\
ZPB & 0.00 \\
ZPC & 0.06 \\
\hline
\end{tabular}

Values are the average of duplicate analyses.

bonds in ZPA and ZPB are formed during fertilization. However, a similar amount of the bimane group was incorporated into ZPC of the zona pellucida of fertilized and ovarian eggs (Fig. 3 and Table 2), indicating that during fertilization oxidation of cysteine residues in ZPC is low.

$\mathrm{N}$-terminal peptide $(21 \mathrm{kDa})$ and $\mathrm{C}$-terminal peptide $(63 \mathrm{kDa})$ are cross-linked through disulfide bonds in a portion of ZPA (76 kDa) of the zona pellucida of ovarian eggs (Noguchi et al., 1994). In addition to a band of $76 \mathrm{kDa}$, the bands of both peptides were present in SDS-PAGE under reducing conditions (Fig. 4c, lane 4). No band of $76 \mathrm{kDa}$ was detected in the zona pellucida of fertilized eggs (Fig. 4d, lane 4), indicating that ZPA underwent complete cleavage to 21 and $63 \mathrm{kDa}$ peptides during fertilization. N-terminal sequences of the 21 and $63 \mathrm{kDa}$ peptides were determined to 


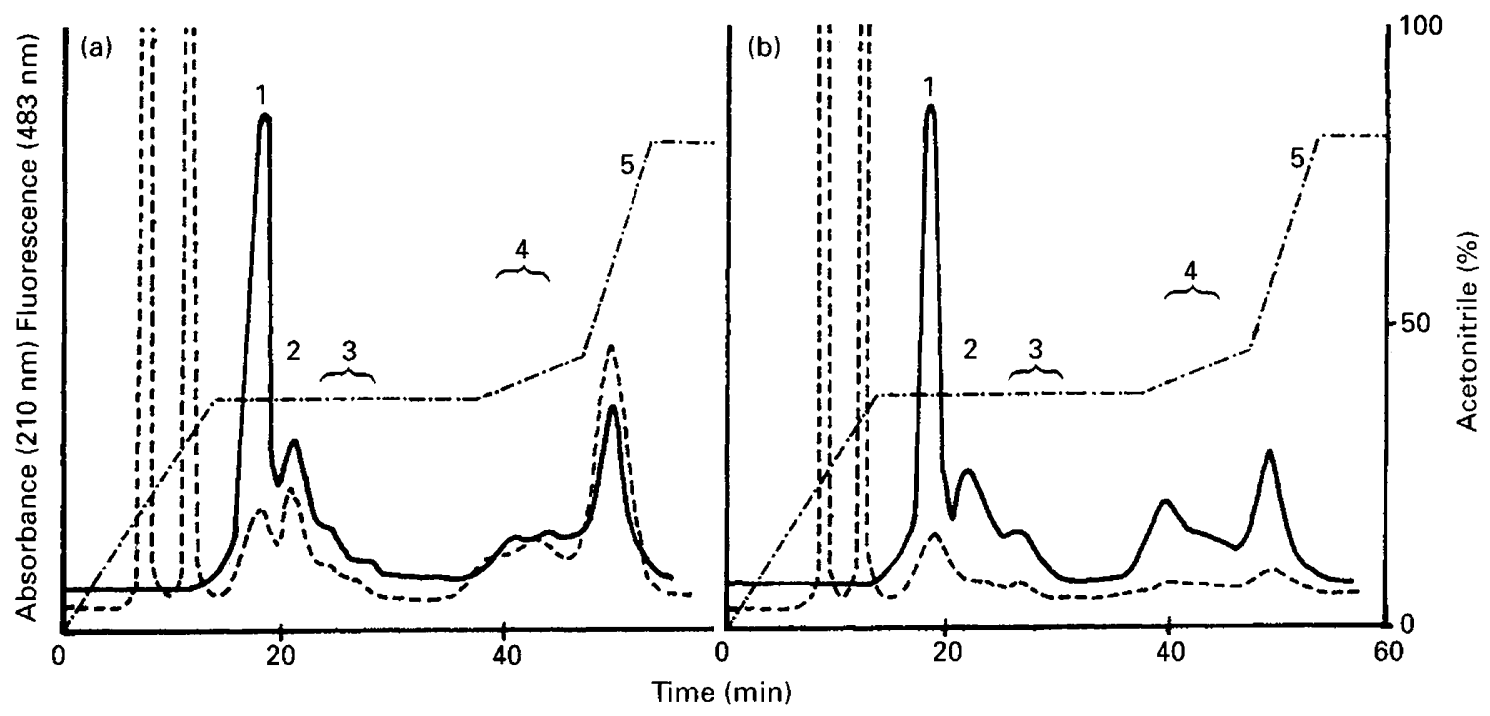

Fig. 3. Fractionation of monobromobimane $(\mathrm{mBBr})$-modified bovine zona pellucida proteins after digestion with endo- $\beta$-galactosidase. The digests of mBBr-zona pellucida proteins from ovarian eggs (a) and fertilized eggs (b) ( $n=3000$ in each group) were subjected to chromatography on a Nucleosil $300-7 \mathrm{C} 18$ column $(4 \mathrm{~mm} \times 150 \mathrm{~mm})$ by an increasing concentration of acetonitrile (----) in $0.1 \%$ (w/v) trifluoroacetic acid at a flow rate of $1.0 \mathrm{ml} \mathrm{min}$. An identical amount of protein estimated by amino acid analysis was applied in each chromatography. Absorbance at $210 \mathrm{~nm}(-)$ and fluorescence intensity at $483 \mathrm{~nm}(---)$ with excitation at $405 \mathrm{~nm}$ were monitored. The numbers indicate fractions $1-5$.

(a)

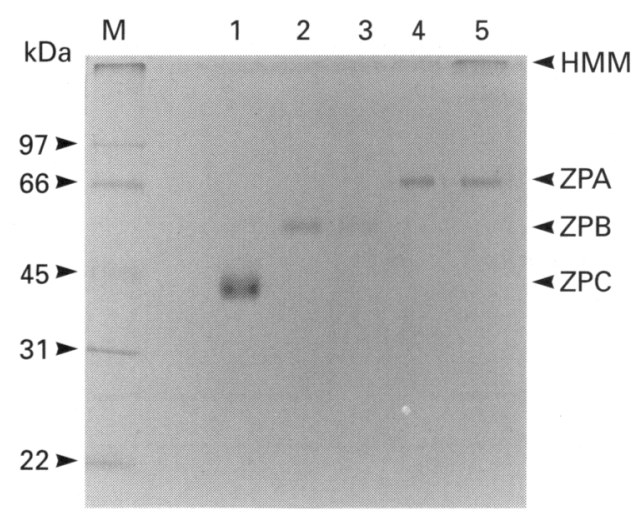

(c)

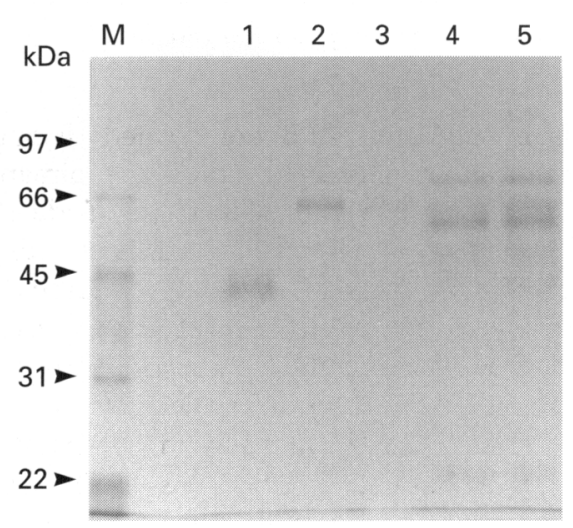

(b)

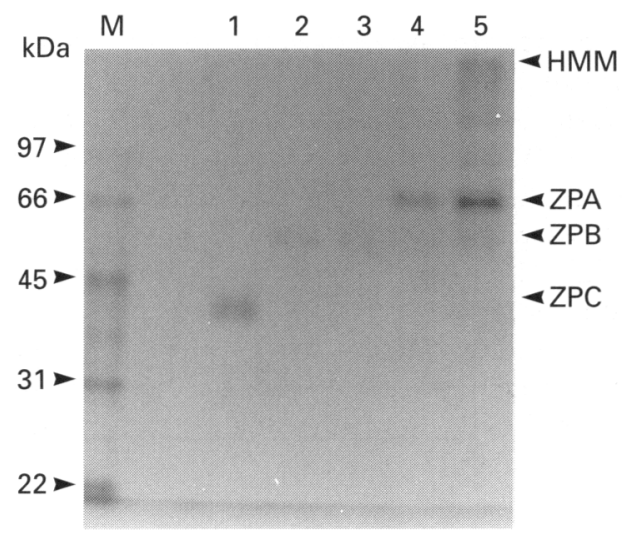

(d)

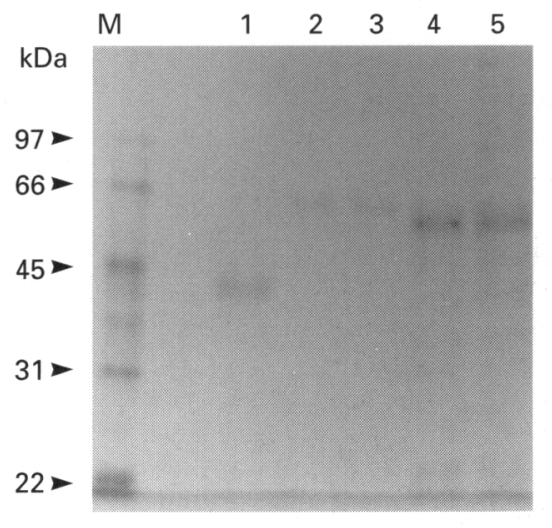

Fig. 4. SDS-PAGE of bovine zona pellucida protein fractions from reverse-phase HPLC. Zona pellucida proteins were isolated from ovarian eggs $(a, c)$ and fertilized eggs (b,d). Fractions 1-5 from the HPLC (Fig. 3) were subjected to electrophoresis in lanes 1-5, respectively, on an 11\% acrylamide gel under non-reducing $(a, b)$ and reducing conditions $(c, d)$. HMM: high molecular mass multimers; M: molecular mass markers. Proteins were silver stained. 
be IleAspGlyValAsnGInLeu and AspAspThrAlaGlyProLys, respectively. The sequence of the $76 \mathrm{kDa}$ protein (ZPA) was the same as the $21 \mathrm{kDa}$ peptide.

The last peaks in the reverse-phase HPLC (Fig. 3) were separated into three fractions by gel filtration HPLC (Fig. $5 a, b)$. The incorporation of the bimane group into the multimers also decreased after fertilization (Fig. 5b, fractions 4 and 5). SDS-PAGE of each fraction under non-reducing conditions showed that the ZPA monomer was eluted in fractions 3 and 6 (Fig. 5c, lanes 3 and 6). Under reducing conditions, only one main band was released from the multimers of the zona pellucida proteins in fertilized eggs (Fig. 5d, lanes 4' and '5'). The molecular mass of ZPB digested with endo- $\beta$-galactosidase is $68 \mathrm{kDa}$ (Noguchi et al., 1994) which is similar to the $63 \mathrm{kDa}$ peptide from ZPA (Fig. 5d). The position of the dense band in the separation of the high molecular mass multimers (Fig. 5d, lanes $4^{\prime}$ and $5^{\prime}$ ) indicates that the multimers formed during fertilization are constructed mainly from ZPB.
Estimation of the amount of bimane group incorporated into the three components

The amount of the bimane group incorporated into the three components was estimated as described earlier. Incorporation of the bimane group into $\mathrm{ZPA}$ and $\mathrm{ZPB}$ was almost undetectable after fertilization, whereas incorporation into ZPC was similar in the zonae pelludicae of fertilized and ovarian eggs (Table 2).

\section{Discussion}

The bovine zona pellucida was insoluble in isotonic medium at $\mathrm{pH} 3.0$, although the zona pellucida of pig ovarian eggs is solubilized within about $20 \mathrm{~s}$ in lactic acid-PBS at $\mathrm{pH} 3.6$ (Hatanaka et al., 1992). In acidic Tyrode's solution, pH 2.5, the time for lysis of the hamster zona pellucida is $30-60 \mathrm{~s}$ and for mouse and rat zona pellucida is 5-10 s (Nicolson et al.,
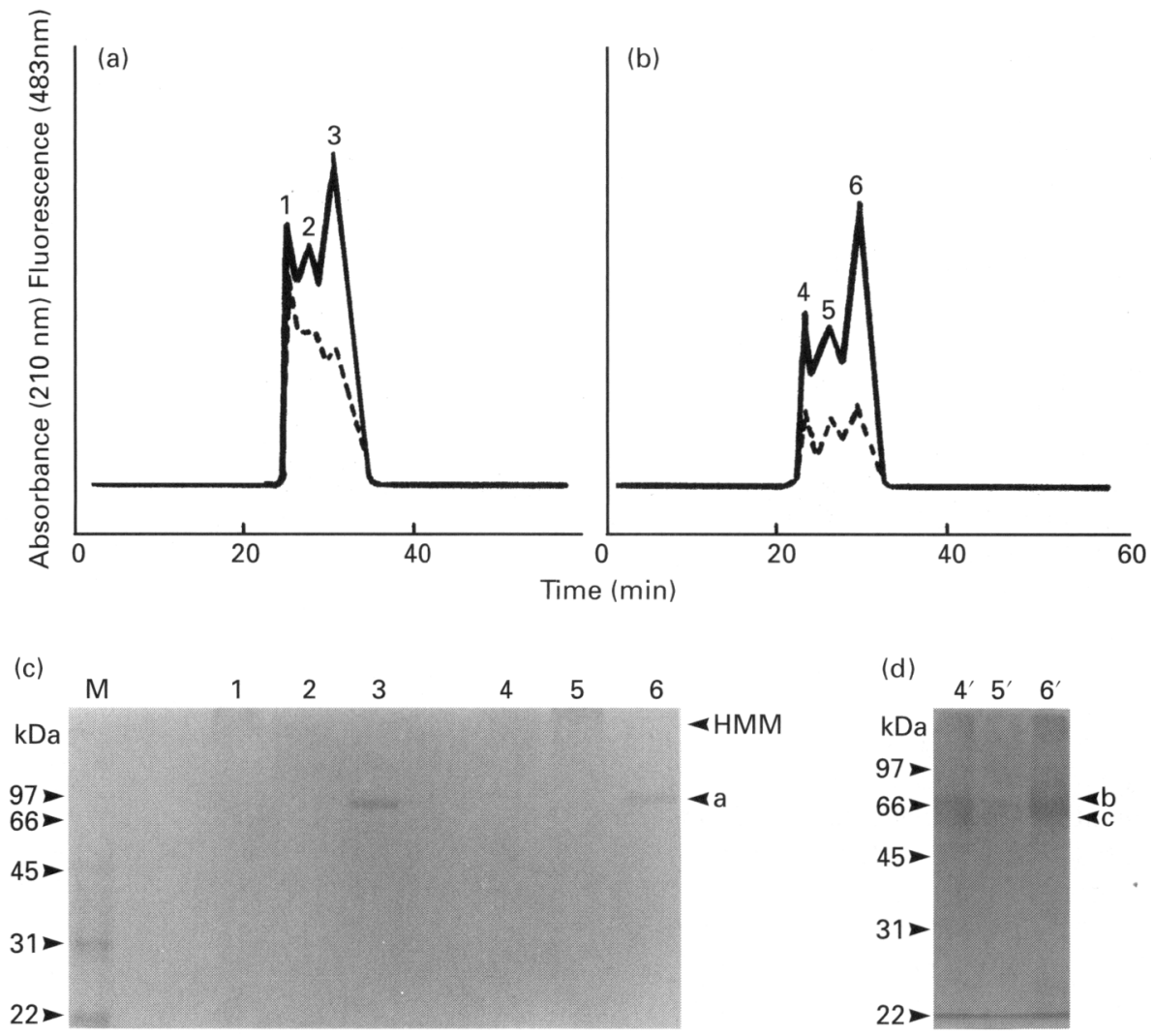

Fig. 5. Separation of fraction 5 from reverse-phase HPLC of bovine zona pellucida proteins (Fig. 3) into high molecular mass multimers and ZPA by gel filtration HPLC. Fraction 5 (Fig. 3) was subjected to chromatography on a TSK-gel G3000SW column $(7.5 \mathrm{~mm} \times 60 \mathrm{~cm})$ by elution with 3.5 mmol SDS l-1,100 mmol sodium sulfate $\mathrm{l}^{-1}$ and $50 \mathrm{mmol}$ sodium phosphate $\mathrm{l}^{-1}$ (pH 7.0) at a flow rate of $0.4 \mathrm{ml} \mathrm{min}{ }^{-1}$. Fraction 5 from the zona pellucida proteins of ovarian eggs (a) (Fig. 3a), and fertilized eggs (b) (Fig. 3b). Absorbance at $210 \mathrm{~nm}$ (-) and fluorescence intensity at $483 \mathrm{~nm}(---)$ with excitation at $405 \mathrm{~nm}$ were monitored. SDS-PAGE of the fractions of gel filtration HPLC on a $11 \%$ acrylamide gel under non-reducing conditions (c) and on a 12.5\% acrylamide gel under reducing conditions (d). Lanes 1-6 in (c) and lanes $4^{\prime}-6^{\prime}$ in (d) correspond to fractions 1-6 and 4-6, respectively. Arrowheads $a, b$ and $c$ indicate the position of bands of ZPA, ZPB and the $63 \mathrm{kDa}$ fragment of ZPA, respectively. HMM: high molecular mass multimers; M: molecular mass markers. Proteins were silver stained. 
1975). These observations indicate that the bovine zona pellucida has a more rigid structure than that of rodents and pigs. The bovine zona pellucida was also resistant to $\beta$ mercaptoethanol and urea; the time for solubilization in a hypotonic buffer containing $5 \%(\mathrm{v} / \mathrm{v}) \beta$-mercaptoethanol and 7 mol urea $1^{-1}$ was $>11$ min. For solubilization of the zona pellucida, cleavage of hydrogen bonds as well as reduction of disulfide linkages must be necessary. The time for lysis of the zona pellucida of fertilized eggs was about $10 \%$ greater than that of ovarian eggs. This increase in solubilization time did not change markedly from the two-cell stage to the morula stage.

The presence of free thiols in the unfertilized and fertilized eggs was investigated using the fluorescent probe, $\mathrm{mBBr}$, which reacts specifically with thiol groups under physiological conditions (Kosower et al., 1979; Kosower and Kosower, 1987). mBBr has been used mainly for the analysis of thiol and disulfide status in mammalian spermatozoa (Seligman et al., 1991; Seligman et al., 1994; Yossefi et al., 1994). This probe is suitable for modification of the zona pellucida, since there is a possibility that the architecture of the zona pellucida is changed in hypotonic and hypertonic solutions (Hatanaka et al., 1988). The zonae pellucidae isolated from ovarian eggs were strongly coupled with bimane group in PBS, while those from fertilized eggs were weakly coupled.

In neutral and alkaline media at $37^{\circ} \mathrm{C}$, disulfide interchange in peptides occurs and this reaction is triggered by the thiol group (Jensen, 1959). An intramolecular thioldisulfide interchange is followed by intermolecular exchange, leading to polymerization which is accelerated at higher temperatures. A similar reaction might be induced during solubilization of the zonae pellucidae of ovarian eggs. During solubilization, free thiols in the zonae pellucidae of ovarian eggs probably trigger the formation of high molecular mass multimers cross-linked through intermolecular disulfide linkages. The multimers detected as an immobile band in the SDS-PAGE were eluted in the last peak in the reverse-phase HPLC together with a portion of ZPA.

The free thiols in the isolated zonae pellucidae are modified with $\mathrm{mBBr}$ and the modified residues no longer trigger the formation of multimers during solubilization. Treatment with $\mathrm{mBBr}$ for $1 \mathrm{~h}$ may be insufficient for complete modification of the zona pellucida, and the residual unmodified thiols trigger the formation of multimers during solubilization. Treatment of zonae pellucidae from ovarian eggs with $\mathrm{mBBr}$ for $6 \mathrm{~h}$ significantly reduced the amount of multimers and their fluorescence intensity (data not shown).

Measurement of the relative fluorescence intensity compared with mB-glutathione revealed that the thiol content of zonae pellucidae of fertilized eggs was about $14 \%$ of that of ovarian eggs. The multimers were also produced in the zonae pellucidae of fertilized eggs, although the amount was smaller than in the ovarian eggs.

The results of this study indicate that the disulfide bonds in ZPA formed during fertilization are predominantly intramolecular linkages. The oxidation may be induced after specific cleavage by a protease released from the oocyte. The findings of the present study indicate that the specific cleavage site of ZPA is the amino group side of the Asp residue. During fertilization in pigs, $\mathrm{ZPA}(90 \mathrm{kDa})$ protein is specifically cleaved at the peptide bond between Ala and Asp residues into 25 and $65 \mathrm{kDa}$ peptides (Hatanaka et al., 1992; Hasegawa et al., 1994). A protease with similar specificity may be released at fertilization in both species. In $\mathrm{ZPB}$, intra- and intermolecular disulfide bonds are formed. In contrast to $\mathrm{ZPA}$ and $\mathrm{ZPB}$, oxidation of cysteine residues in ZPC during fertilization is low.

The positions of cysteine residues in the zona pellucida proteins are highly conserved (Harris et al., 1994) and most of these residues form disulfide linkages, contributing mainly to the maintenance of the zona pelludica structure (Dunbar, 1983; Dunbar et al., 1994). Although the amino acid sequence of bovine ZPA has not been determined, this component, which is homologous to pig ZPA, is thought to have 20 cysteine residues. The results of the present study indicate that a small number of the cysteine residues are present in the reduced state in the unfertilized egg. It is postulated that the formation of intra- and intermolecular disulfide linkages during fertilization induces the construction of a more rigid structure, so that more time is required for solubilization of the zona pellucida in $\beta$-mercaptoethanol-urea solution.

Bovine ZPA is cleaved specifically by proteases during fertilization (Noguchi et al., 1994). The mechanism by which the proteolysis induces the conversion of thiols to disulfides in the native zona pellucida structure remains unclear. It is likely that the conversion causes the hardening of the zona pellucida which is responsible for blocking polyspermy.

This study was supported in part by a Grant-in-Aid for Scientific Research from the Ministry of Education, Science and Culture of Japan.

\section{References}

Austin CR and Braden AWH (1956) Early reactions of the rodent egg to spermatozoon penetration Journal of Experimental Biology 33 358-365

Barros C and Yanagimachi R (1971) Induction of zona reaction in golden hamster eggs by cortical granule material Nature 233 268-269

Bleil JD and Wassarman PM (1980) Structure and function of the zona pellucida: identification and characterization of the proteins of the mouse oocyte's zona pellucida Developmental Biology 76 185-202

Bleil JD, Beall CF and Wassarman PM (1981) Mammalian sperm-egg interaction: fertilization of mouse eggs triggers modification of the major zona pellucida glycoprotein, ZP2 Developmental Biology 86 189-197

Brackett BG and Oliphant G (1975) Capacitation of rabbit spermatozoa in vitro. Biology of Reproduction 12 260-274

Braden AWH, Austin CR and David HA (1954) The reaction of the zona pellucida to sperm penetration Australian Journal of Biological Science 7 391-409

Drobnis EZ, Andrew JB and Katz DF (1988) Biophysical properties of the zona pellucida measured by capillary suction: is zona hardening: a mechanical phenomena? Journal of Experimental Zoology 245 206-219

Dunbar BS (1983) Morphological, biochemical, and immunological characterization of the mammalian zona pellucida. In Mechanism and Control of Animal Fertilization pp 139-175 Ed. JF Hartmann. Academic Press, New York

Dunbar BS, Avery S, Lee V, Prasad LS, Schwahn D, Schwoebel E, Skinner S and Wilkins B (1994) The mammalian zona pellucida: its biochemistry, immunochemistry, molecular biology, and developmental expression Reproduction, Fertility and Development 6 331-341

Foerder CA and Shapiro BM (1977) Release of ovoperoxidase from sea urchin eggs hardens the fertilization membrane with tyrosine crosslinks Proceedings National Acadenty of Sciences USA 74 4214-4218 
Hamano S and Kuwayama M (1993) In vitro fertilization and development of bovine oocytes recovered from the ovaries of individual donors: a comparison between the cutting and aspiration method Theriogenology 39 703-712

Harris JD, Hibler DW, Fontenot GK, Hsu K'T, Yurewicz EC and Sacco AG (1994) Cloning and characterization of zona pellucida genes and CDNA from a variety of mammalian species: the $\mathrm{ZPA}, \mathrm{ZPB}$ and $\mathrm{ZPC}$ families $D N A$ Sequence 4 361-393

Hasegawa A, Koyama K, Okazaki Y, Sugimoto M and Isojima S (1994) Amino acid sequence of porcine zona pellucida glycoprotein ZP4 determined by peptide mapping and cDNA cloning Journal of Reproduction and Fertility 100 245-255

Hatanaka Y, Nakano $\mathbf{M}$ and Tobita T (1988) Modification of porcine zona pellucida with fluorescein isothiocyanate: evidence for the presence of a structural unit consisting of glycoproteins in the mammalian egg coat Biochemistry International $17935-944$

Hatanaka Y, Nagai T, Tobita T and Nakano M (1992) Changes in the properties and composition of zona pellucida of pigs during fertilization in vitro. Journal of Reproduction and Fertility 95 431-440

Hedrick JL (1996) Comparative structural and antigenic properties of zona pellucida glycoproteins Journal of Reproduction and Fertility Supplement $\mathbf{5 0}$ 9-17

Hedrick JL, Wardrip NJ and Berger T (1987) Difference in the macromolecular composition of the zona pellucida isolated from pig oocytes, eggs and zygotes fournal of Experimental Zoology $241257-262$

Jensen EV (1959). Sulfhydryl-disulfide interchange Science 130 1319-1323

Kosower NS and Kosower EM (1987) Thiol labeling with bromobimanes Methods in Enzymology 143 76-84

Kosower NS, Kosower EM, Newton GL and Ranney HM (1979) Bimane fluorescent labels: labeling of normal human red cells under physiological conditions Proceedings National Academy of Sciences USA 76 3382-3386

Moller CC and Wassarman PM (1989) Characterization of a proteinase that cleaves zona pellucida glycoprotein ZP2 following activation of mouse eggs Developmental Biology 132 103-112
Nakano M, Hatanaka Y, Sawai T, Kobayashi N and Tobita T (1987) Fractionation of glycoproteins from porcine zonae pellucidae into three families by high-performance liquid chromatography Biochemistry International 14 417-423

Nicolson GL, Yanagimachi R and Yanagimachi H (1975) Ultrastructural localization of lectin-binding sites on the zonae pellucidae and plasma membranes of mammalian eggs Journal of Cell Biology 66 263-274

Noguchi S, Yonezawa N, Katsumata T, Hashizume $K$, Kuwayama $M$, Hamano S, Watanabe S and Nakano M (1994) Characterization of the zona pellucida glycoproteins from bovine ovarian and fertilized eggs Biochimica et Biophysica Acta 1201 7-14

Schmell ED and Gulyas BJ (1980) Ovoperoxidase activity in ionophore treated mouse eggs II. Evidence for the enzyme's role in hardening the zona pellucida Gamete Research 3279-290

Seligman J, Shalgi R, Oschry Y and Kosower NS (1991) Sperm analysis by flow cytometry using the fluorescent thiol labeling agent monobromobimane Molecular Reproduction and Development 29 276-281

Seligman J, Kosower NS, Weissenberg R and Shalgi R (1994) Thiol-disulfide status of human sperm proteins Journal of Reproduction and Fertility 101 $435-443$

Stewart-Savage J and Bavister BD (1988) A cell surface block to polyspermy occurs in golden hamster eggs Developmental Biology 128 150-157

Wolf DP (1981) The mammalian egg's block to polyspermy. In Fertilization and Embryonic Development In Vitro pp 183-197 Eds L Mastroianni and JD Biggers. Plenum Press, New York

Yanagimachi R (1994) Mammalian fertilization. In The Physiology of Reproduction 2nd Edn pp 189-318 Eds E Knobil and JD Neil. Raven Press, New York

Yossefi S, Oschry Y and Lewin LM (1994) Chromatin condensation in hamster sperm: a flow cytometric investigation Molecular Reproduction and Development 37 93-98

Zhang X, Rutledge J and Armstrong DT (1991) Studies on zona hardening in rat oocytes that are matured in vitro in a serum-free medium Molecular Reproduction and Development 28 292-296 